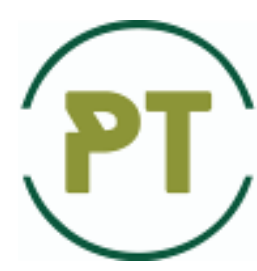

\title{
Creation of theoretical bases of tribotechnologies of running-in and restoration as means of effective increase of operational wear resistance of motor transport and mobile agricultural machinery
}

\author{
V.V. Aulin, S.V. Lysenko, A.V. Hrinkiv, V.V. Slon, A.E. Chernai \\ Central Ukrainian National Technical University, Ukraine \\ E-mail: AulinVV@gmail.com
}

\begin{abstract}
The bases for creation of theoretical bases of tribotechnologies of running-in and restoration of conjugations of details of systems and units of motor transport and mobile agricultural machinery are defined.

The specifics of selective transfer on the surface of contacting parts of machines and creation of servito films, formation of coatings during running-in and restoration from antifriction materials, which are a part of additives in motor and transmission oil, are considered.

A number of tribophysicochemical processes that occur in the conjugations of parts materials and how they affect the creation of tribotechnologies of running-in and restoration are clarified. The creation of tribotechnologies using geomodifiers is considered. It is proposed to build a single theory of tribotechnologies of running-in and recovery on the basis of the mechanism of triboplasm formation in the conjugations of parts of systems and units of machines. It is also proposed to add to this the thermofluctuation theory of S.M. Zhurkova taking into account the change of dilaton and compression bonds of atoms of materials of tribocouples of details with creation of local areas of deformations of compression and tension and zones of thermoplastic deformation.
\end{abstract}

Key words: tribotechnologies of running-in and restoration, conjugation of details, triboplasm, oil, additive, motor vehicles, mobile agricultural machinery

\section{Introduction}

Recently, most consumers of motor transport (MTM) and mobile agricultural machinery (MACM) are insufficiently informed about the achievements of tribology in issues: modern quality and tribological properties of motor and transmission oils, special means of improving them and the possibilities of tribotechnologies of running and recovery. To some extent, this is due to the lack of training of engineering and technical staff and consumers for the perception of new advances in the science of friction, wear and lubrication in machines.

One of the most interesting drugs of modern car chemistry used in practice are complexes of triple compounds (additives) designed to reduce the effects of friction, wear intensity and renovation of couplings of engine parts and transmissions of motor and mobile agricultural machinery.

The vast majority of manufacturers of motor and transmission oils in relation to these triplets, are usually negative. Due to the fact that, in their opinion, modern lubricants already contain all the necessary package of functional additives, and the introduction of additional components in them is not only undesirable, but possibly harmful, due to the imbalance of properties.

However, experience and research [1,2] show that functional additives and additives determine the operation of the conjugations of parts in normal conditions, mainly hydrodynamic friction and in no way take into account the real state of their working surfaces. Note also that they work the same for both new and worn couplings of engine parts and transmissions. At the same time, the lubrication conditions for different stages of operation of motor vehicles and mobile agricultural machinery differ significantly. Wear of friction surfaces during operation makes individual differences in the operation of each triad of parts of systems and units of machines, and therefore when developing tribotechnologies of running-in and restoration it is necessary to take into account the dynamics of changes in characteristics and properties of oils with additives and additives. Note 
that their condition, operating conditions at different stages of the life cycle and the condition of the working surfaces of the parts changes significantly. The solution to this problem and the problems that arise from it are certainly relevant.

\section{Literature review}

Any triad coupling of parts of MTM and MACM systems and units in the simplest embodiment is three components, two of which are conjugate friction surfaces of parts, the third is a film of lubricant or lubricating medium that separates these surfaces $[3,4]$. Packages of additives in oils determine the properties of only the third component - the oil film, with virtually no effect on the properties of work surfaces and materials of the other two [1,5]. In recent years, tribologists are actively searching for additives or catalysts that synthesize in the oil and form films on the friction surface of the conjugation of parts of systems and units of machines.

The results of research show that the acquired average characteristics and properties of oils are not enough to fully protect the reliable and efficient operation of triad couplings of parts of systems and units and MTM and MACM in general. Accordingly, in some cases, it is still recommended to add additives to the engine and transmission oil [5,6]. This is not the only way to increase the operational reliability of machines, because from an economic point of view it is justified that first of all it is necessary to change not the characteristics and properties of oil, but the characteristics and properties of working surfaces MTM and MACM.

Processing of tribocouples of parts by tribocomposition of composite additives changes the characteristics and properties of working surfaces of parts: roughness, friction coefficient, wear intensity, burr force, hardness, microgeometry, gaps between the couplings and others.

Properly designed and competently developed technology for processing the couplings of engine parts and transmission triboskladom and created composite oil can significantly improve the tribotechnical characteristics of the couplings of parts of systems and units in any mode of their operation. However, as studies have shown $[7,8]$, the greatest effect is achieved in those modes where the most likely to violate the standard modes of lubrication of the tribocouple parts. This is observed at rated loads, high load modes and low speeds. Due to the fact that in these modes the hydrodynamics of tribocouples of parts of systems and units of machines is disturbed, the work of standard packages of lubricants and additives is inefficient, and the condition of working surfaces becomes decisive for power losses and wear of engine and transmission parts $[9,10]$.

However, the situation is far from clear, as currently on the market of autochemicals there are many different functional additives and additives to oils, different mechanisms of action. Incompetent use of these drugs can not only dramatically reduce the positive effect, but also lead to significant negative consequences.

At the same time, it is important to ask at what stage of operation the engine and transmission oil should be treated with one or another triad of substances. The vast majority of car owners in the process of operation bring the coupling of engine parts and transmission to a working condition, and then try to resuscitate it by using tribotechnologies running and recovery [11,12]. In some cases, it is possible to partially restore the size of the parts, but their shape, initial surface hardness, elasticity of the piston rings, the shape of the profile of the side surface of the piston can not be reproduced [1,14-16].

According to the results of studies [15,17-20] related to the introduction of tribotechnologies of runningin and recovery, the best effect can be achieved with an average degree (up to 50\%) of wear and tear of engines and transmissions of motor vehicles and mobile agricultural machinery. In practice, engines whose oils are treated with a tribocomposition of additives before running-in, or in the process of running-in have 3 times more service life and no breakdowns, in contrast to untreated motor oil [1,21-23].

Thus, the use of a triad of additives and additives in engine and transmission oils can be an effective way to influence the operational reliability of MTM and MACM, and, in particular, their power units and transmissions.

\section{Purpose}

The aim of this work is from the tribophysicochemical and tribofluctuation points of view to theoretically substantiate the impact of processes occurring in the friction zone of parts, on increasing operational durability and reliability of motor and mobile agricultural machinery by changing the characteristics and properties of their working surfaces. in tribotechnologies of running-in and restoration.

\section{Results}

In the development of tribotechnologies of running-in and restoration of resource-determining conjugations of machines, a single class of antifriction additives has been sufficiently studied. This class of additives is based on the discovery of № 41 of September 13, 1966. The effect of selective friction transfer ("Effect of wear". The authors of the discovery are Ph.D., Professor D.N. Garkunov and Ph.D., Professor V.I. Kragelsky. When rubbing copper alloys on steel in limit lubrication, which eliminates the oxidation of copper, there is a phenomenon of selective transfer of copper from a solid solution of copper alloy to steel and its reverse 
transfer from steel to copper alloy, accompanied by a decrease in friction to the characteristic value when working in a liquid medium and leads to significant wear triad couplings of details.

As a result of the sampling process, tribological, physical and chemical processes take place on the surface of the contacting parts, which lead to the formation of a protective servo film, which cannot be destroyed by friction, because it creates it. The discovery of selective friction transfer in triad couplings of machine parts allowed to develop a number of fundamentally new materials of functional additives and additives to motor and transmission oils and tribotechnologies, which are widely used to significantly reduce running time and increase the service life of triad couplings of parts, systems and units.

The results of the study indicate that the formation of protective servito films can occur in the conjugations of parts whose materials do not contain copper or other plastic alloys. To do this, the necessary components of additives and additives are introduced into the lubricant. This principle underlies the development of metal-plating additives and tribotechnologies of running-in and restoration [24]. In the development of tribotechnologies of reduction, the composition of metal-plating additives mostly includes $C u$ - copper, $\mathrm{Zn}$ - zinc, $N i$ - nickel, $S n$ - tin, $A g$ - silver, $C u S n$ - bronze, $C u Z n$ - brass. These metals and alloys with a dispersion of about $100 \mathrm{~nm}$ should be placed in a special liquid composition - an organic complexing agent.

Theoretical bases of creation and functioning of tribotechnologies of running-in and restoration in the final version are not created. In the implementation of such technologies, the formation of antifriction film occurs in the conditions of shear and plastic deformations, high specific loads and temperatures. The film formed under the conditions has special properties: a large degree of porosity of the working surface of the parts, the parameter of the crystal lattice of the film material is different from the parameter of the lattice of the base metal of the part.

Since during normal friction the parts are in contact on a very small area, which is $0.01 \ldots 0.0001$ of the area of the conjugate surfaces, the contact areas have high concentrations of mechanical stresses, which causes intense wear. When metal-clad additives are introduced into the lubricant, a servolite film is formed from nanometric metal clusters. Based on the metal-plating additive with a particle size less than $100 \mathrm{~nm}$, charged particles or micelles are formed in the lubricant. The direction of movement of micelles in the lubricant is due to the potential difference that occurs in the triad couplings of parts during their operation. At the initial moment of contact, when the metal particles are positively charged, the destruction of micelles occurs on one surface of the part. Then there is a recharge, and a similar process takes place on another surface of the conjugate part or sample. Charged particles are transferred to the contact micro-irregularities of the roughness of the working surface of the part, and then there is a filling and depressions of micro-irregularities. The described process continues until the formation of friction on both surfaces of the servo film with a thickness of $1 \ldots 3 \mu \mathrm{m}$, after which the transfer process is stopped and the passivation mode occurs. The thickness of the formed servo film corresponds to the sizes of microroughnesses (or overlaps them) of the majority of details of motor transport and mobile agricultural machinery.

This is the theoretical tribophysical and experimental basis for the creation and application of tribotechnologies of running-in and restoration of conjugated parts of systems and units of machines. During selective transfer, the friction process is carried out through a plastically deformed soft and thin layer of metal. In this case, the area of actual contact increases by 10-100 times, and the material of the parts experiences only elastic deformations. In addition to increasing the actual contact area, thin films of antifriction material themselves reduce the friction between the solid tangential surfaces and the coefficient of friction becomes close to the coefficient of liquid friction. The metal-plating servo film formed in the contact zone is a nanoobject and behaves like a newtonian fluid under tensile and compressive conditions and, as a result, becomes unbearable and superficial $[1,2,24]$.

It was found that when using a tribocomposite material - geomodifier [25] (additives KGMF-1) in the developed tribotechnology we obtain the following:

- increases the compression of the engine by $0.2-0.5 \mathrm{MPa}$;

- reduced consumption of engine oil for burnout in 1.0-1.5 times;

- reduced fuel consumption per $100 \mathrm{~km}$;

- the content of $\mathrm{CO}$ and $\mathrm{CH}$ in the exhaust gases decreases by 1.5-2.0 times;

- increases the resource and operational reliability of engines and transmissions of machines;

- noise and vibrations in MTM and MACM systems and units are reduced;

- operating temperatures in the friction zone of resource-determining couplings of engine parts and transmissions are reduced.

When creating tribotechnologies use tribophysicochemical processes occurring in the composite oil and its interaction with the working surface of the conjugation of parts. However, it should be noted the lack of a strict unified theory, which would theoretically from a tribophysical point of view would justify complex and diverse tribophysicochemical phenomena and processes caused by the interaction between additive particles or components of geomodifiers, with oil and working surfaces. The most appropriate is a model approach using the percussion mechanism of interaction. Based on this approach, it is possible to identify a complex combination of deformation-structural, thermal, electromagnetic, optical and chemical processes. These include the occurrence and migration of defects in the structure of the materials of the parts, their amorphization and rapid local heating at the point of contact. At the same time, chemical bonds are broken during the formation of a fresh surface, and 
short-lived active centers are formed on it. To the full picture of the phenomena should be added the emission of electrons, photons, ions and the emergence of electrostatic charge.

The only theory that can explain the formation of films on the friction surfaces of tribocouples of parts is a model representation of the mechanism of triboplasm formation. The power of analogies and model representation of phenomena and processes observed at nano-, micro-, meso- and macro-levels are also used. The interaction of the conjugations of the parts during operation and grinding of the particles of the components of the geomodifier of the additive material, leads to the concentration of energy in the microlocal surface area of the contacting parts. As a result, the formation of a thin layer of melt is possible for short periods of time, and even the transition of the substance to a high-energy state similar to the plasma state is observed [26].

In addition, the thermofluctuation theory of S.M. Zhurkova [24]. The state of the working surface of the conjugations of parts is also formed under the influence of changes in the dilaton and compression bonds of atoms of materials in their local regions. The transition of materials in the contact zone from nonequilibrium to equilibrium, the formation of nano-, micro-, meso- and macro-destruction depends on the acquisition of electromagnetic dipoles of local areas of dilaton or compression connections between them and their mutual transition. In solid state physics, this is due to the parallelism and antiparallelism of the spins and the creation of local areas of tensile or compressive strain.

These issues in tribotechnologies of running-in and recovery require careful study.

Since the process of friction is a set of a large number of acts of mechanical interaction of microirregularities of conjugate surfaces of parts, the protrusions of micro-contacts that slide towards each other are in a state of impact - elastic or plastic. This interaction occurs during $10^{-7}-10^{-8} \mathrm{~s}$, during which a lot of energy is supplied to the tribocontact. The area of local heating is on average $10^{-2}-10^{-4} \mathrm{~cm}^{2}$, and the duration of formation and existence of triboplasma is of the order of $10^{-5}-10^{3} \mathrm{~s}$.

This makes it possible to explain most of the phenomena that accompany the tribochemical activation of materials in the contact zone. The model of the plasma state of the tribocontact of parts, the energy released during loading on the materials of the tribocouples of parts, shows that it can significantly exceed the heat of fusion and due to low thermal conductivity leads not only to melting but also to sublimation. The substance is in the contact zone in the form of ions and electrons, ie there is a plasma state.

It is established that for the conditions of realization of tribo technologies of running-in and restoration the laws of classical thermodynamics are not fulfilled, and characteristics and properties of material of a thin surface layer of details essentially change, because of formation in a zone of friction of triboplasm. The process of its creation is accompanied by the emission of electrons, which from the friction surface is directed into the lubricant, in which there is a certain catalyst for antifriction films in the form of certain components of the geomodifier.

Electrons, colliding with atoms of lubricant and atoms of matter components of the geomodifier introduced as a catalyst for the formation of films convert them. The ionic decay of the catalyst structure of the components is observed. This process triggers a mechanism, the end result of which is the formation on the friction surfaces of the conjugations of the parts of the protective films, consisting of wear products of the starting materials of tribochemical reactions and a modified form of carbon. The consequence of the above processes is the selective adsorption of carbon ions, which build a crystal lattice of the solid phase on the metal surface of the parts under the action of cohesive forces. Note that due to the peculiarities of the triggered mechanisms, the catalyst for protective films and coatings is equally effective for surfaces of ferrous and nonferrous metals.

The observed plasma state of the surface layers of the conjugations of the parts emits triboplasm in their sliding contact. This is caused by frictional heating or high energy formed in the deformed layer by the sliding contact. In addition, the intensity of radiation around the sliding contact increases with increasing resistivity of materials. This indicates that the triboplasm is generated by electrification by friction.

For a better understanding of such triboplasm by friction, further research is needed, as it is a completely new direction in the field of tribotechnology of running-in and restoration of conjugated parts. From a practical point of view, this allows using a synthesized catalyst to process and restore worn surfaces of parts in the normal operation of systems and units of motor vehicles and mobile agricultural machinery.

The proposed additives in tribotechnologies must be compatible with all lubricants used in systems and units of motor vehicles and mobile agricultural machinery.

The high effect from the use of the catalyst of antifriction films is observed in the processing of oils in the couplings of engine and transmission parts, plain and rolling bearings, gearboxes, pumps, drives. The main direction of further promotion of the catalyst as a component of the geomodifier of antifriction films can be the creation of lubricants with high characteristics both in terms of friction coefficient and resource on the developed theoretical foundations of tribotechnologies of running-in and recovery.

\section{Conclusions}

1. It is shown that to increase operational wear resistance and reliability of motor transport and mobile agricultural machinery it is possible by addition of additives and additives to motor and transmission oils, ie changing characteristics and properties of oils. It is substantiated that more effective increase of operational 
reliability can be realized purposefully, changing characteristics and properties of working surfaces of conjugations of details of systems and units by tribotechnologies of their running-in and restoration.

2. The use of metal-clad antifriction additives with nanocomponents in the formation of servomotable films, the implementation of selective transfer processes and changes in the contact area of the conjugations of parts and the formation of micelles in the lubricating medium.

3. From the theoretical point of view the possibilities of tribotechnology of running-in and restoration at use of the KGMF-1 geomodifier are shown and the characteristic processes proceeding thus in triboconjugations of details are considered.

4. It was found that when creating tribotechnologies it is necessary to create a tribophysical and chemical theory that would explain and generalize complex and diverse phenomena and processes caused by the action of different natures of forces in tribocouples of parts with composite oil.

5. It is determined that it is expedient to create a thermofluctuation theory of destruction of materials of conjugations of machine parts under the influence of changing dilaton and compression bonds of their atoms and formation of corresponding local regions of tensile and compressive deformations when creating a tribophysicochemical theory.

6. It is shown that based on the model of triboplasm arising in triboconjugation of parts due to electrification of friction materials, it is possible to explain the mechanism of synthesis of servo-antifriction film on friction surfaces of parts due to mechanochemical activation of their materials in the contact zone.

\section{References}

1. Aulin V.V., Lysenko S.V., Kuzyk O.V., Hrynkiv A.V., Holub D.V. (2016). Trybofizychni osnovy pidvyshchennia nadiinosti mobilnoi silskohospodarskoi ta avtotransportnoi tekhniky tekhnolohiiamy trybotekhnichnoho vidnovlennia: monohrafiia [Tribophysical bases of increase of reliability of mobile agricultural and motor transport technics by technologies of tribotechnical restoration: monograph]. Kropyvnytskyi: Lysenko V. F., 303 c [in Ukrainian].

2. Aulin V.V. (2014). Fizychni osnovy protsesiv i staniv samoorhanizatsii v trybotekhnichnykh systemakh [Physical bases of processes and states of self-organization in tribotechnical systems]. Kirovohrad: Lysenko V.F., 369 c [in Ukrainian].

3. Gorskiy V.V. (1993). Masshtabnyiy skachok i formirovanie amorfno-kristallicheskih splavov v yavlenii strukturnoy prisposablivaemosti metallov pri trenii v aktivnyih sredah [Large-scale jump and formation of amorphous-crystalline alloys in the phenomenon of structural adaptability of metals by friction in active media]. Trenie i iznos - Friction and wear. №1. S.34-41 [in Russian].

4. Aulin V.V., Kuzyk O.V., Lysenko S.V., Verbytskyi O.V. (2017). Osoblyvosti strukturno-fazovykh peretvoren $\mathrm{v}$ materialakh detalei mashyn ta mekhanizmiv pry terti [Features of structural-phase transformations in materials of details of machines and mechanisms at friction]. Problemy konstruiuvannia, vyrobnytstva ta ekspluatatsii silskohospodarskoi tekhniky: materialy XI Mizhnarodnoi naukovo-praktychnoi konferentsii materials of the XI International scientific-practical conference. Kropyvnytskyi: TsNTU, S. 225-227 [in Ukrainian].

5. Aulin V.V., Lysenko S.V., Zhylova I.V., Lysenko V.M. (2017). Fizychna mezomekhanika znoshuvannia robochykh poverkhon detalei trybospriazhen mobilnoi silskohospodarskoi i avtotransportnoi tekhniky [Physical mesomechanics of wear of working surfaces of details of tribocouples of mobile agricultural and motor transport equipment]. Problems of design, production and operation of agricultural machinery: materialy XI Mizhnarodnoi naukovo-praktychnoi konferentsii - materials of the XI International scientificpractical conference. Kropyvnytskyi: TsNTU, S. 223-225 [in Ukrainian].

6. Aulin V.V., Lysenko S.V., Hrynkiv A.V., Chernai A.Ie., Lukashuk A.P. (2018). Mozhlyvosti tekhnolohii trybotekhnichnoho vidnovlennia dlia pidvyshchennia znosostiikosti i dovhovichnosti spriazhen detalei transportnykh zasobiv [Possibilities of tribotechnical restoration technologies for increase of wear resistance and durability of conjugations of details of vehicles]. Suchasni tekhnolohii v mashynobuduvanni ta transporti. Naukovyi zhurnal - Modern technologies in mechanical engineering and transport. Scientific journal, №1(10). S.5-11 [in Ukrainian].

7. Aulin V.V., Dykha O.V., Lysenko S.V., Hrynkiv A.V. (2018). Vplyv rezhymu mashchennia na trybotekhnichni kharakterystyky poverkhni spriazhen detalei dyzeliv avtomobiliv [Influence of lubrication mode on tribotechnical characteristics of the interface surface of diesel car parts]. Innovative technologies for the development and efficiency of road transport: zbirnyk naukovykh materialiv mizhnarodnoi naukovo-praktychnoi internet-konferentsii - a collection of scientific materials of the international scientific-practical Internet conference. TsNTU, m.Kropyvnytskyi, Ukraina, 14-15 lystopada 2018 r.. Kropyvnytskyi. S.218-240 [in Ukrainian].

8. Aulin V.V., Tarnavskyi D.V. (2018). Systemne zastosuvannia trybotekhnolohii prypratsiuvannia i vidnovlennia na etapakh zhyttievoho tsyklu zasobiv transportu [Systematic application of tribotechnologies of running-in and restoration at the stages of the life cycle of vehicles]. Improving the reliability of machinery and equipment: zb. tez dopovidei KhII Vseukrainskoi naukovo-praktychnoi konferentsii studentiv, aspirantiv ta 
molodykh naukovtsiv - Coll. abstracts of the XII All-Ukrainian scientific-practical conference of students, graduate students and young scientists. Kropyvnytskyi: TsNTU, S. 86-87 [in Ukrainian].

9. Aulin V., Zamota T., Hrynkiv A., Lysenko S. at all. (2019). Increase of formation efficiency of gears contact spot at electrochemical-mechanical running-in. Problems of tribology. Khmelnytskyi. KhNU, 24 (4/94). S.33-39 [in English].

10. Aulin V., Zamota T., Hrynkiv A., Lysenko S. at all. (2019). Increase of formation efficiency of gears contact spot at electrochemical-mechanical running-in. Problems of tribology. Khmelnytskyi. KhNU, 24 (4/94). S.33-39 [in English].

11. Aulin V.V., Lysenko S.V., Hrynkiv A.V., Chernai A.E., Lukashuk A.P. (2019). Systemnospriamovanyi pidkhid do rozrobky tekhnolohii bezrozbirnoho vidnovlennia spriazhen detalei [System-oriented approach to the development of technologies for disassembly of conjugation of parts]. Kramarov readings: $z b$. tez dopovidei VI Mizhnarodnoi naukovo-tekhnichnoi konferentsii - collection. abstracts of the VI International Scientific and Technical Conference, 21-22 liut. 2019 r., m. Kyiv, NUBiP. - K.: Vydavnychyi tsentr NUBiP Ukrainy, S. 94-96 [in Ukrainian].

12. Aulin V.V., Lysenko S.V., Zhylova I.V., Verbytskyi O.V. (2019). Synerhetychne pidvyshchennia nadiinosti trybospriazhen detalei system i ahrehativ transportnykh mashyn [Synergetic increase of reliability of tribocouples of details of systems and units of transport cars]. Increase of Machine and Equipment Reliability: materialy loi Mizhnarodnoi naukovo-praktychnoi konferentsii - materials of the 1st International scientificpractical conference, 17-19 kvitnia 2019 r., Kropyvnytskyi: TsNTU, S.7-8 [in Ukrainian].

13. Aulin V.V., Lysenko S.V., Zhylova I.V., Verbytskyi O.V. (2019). Synerhetyka pidvyshchennia znosostiikosti i nadiinosti trybospriazhen detalei system i ahrehativ mashyn [Synergetics of increase of wear resistance and reliability of tribocouples of details of systems and units of cars]. Kramarov readings: $z b$. tez dopovidei VI Mizhnarodnoi naukovo-tekhnichnoi konferentsii - collection. abstracts of the VI International Scientific and Technical Conference, 21-22 liut. 2019 r., m. Kyiv, NUBiP. - K.: Vydavnychyi tsentr NUBiP Ukrainy, S. 127-129 [in Ukrainian].

14. Aulin V.V., Lysenko S.V., Hrynkiv A.V., Zhylova I.V. (2019). Problemy stvorennia smart-pokryttiv v zelenii trybolohii (2019). Increase of Machine and Equipment Reliability: materialy 1oi Mizhnarodnoi naukovo-praktychnoi konferentsii - materials of the 1st International scientific-practical conference, 17-19 kvitnia 2019 r., Kropyvnytskyi: TsNTU, S.53-56 [in Ukrainian].

15. Aulin V., Lysenko S., Lyashuk O., Hrinkiv A., Velykodnyi D., Vovk Y., Holub D., Chernai A. (2019). Wear resistance increase of samples tribomating in oil composite with geo modifier KGMF-1. Tribology in Industry. Vol. 41, No. 2. P. 156-165 [in English].

16. Aulin V., Hrynkiv A., Lysenko S., Dykha A., Zamota T., Dzyura V. (2019). Exploring a possibility to control the stressed-strained state of cylinder liners in diesel engines by the tribotechnology of alignment. Eastern-European Journal of Enterprise Technologies. Vol. 3 (12 - 99). P. 6-16 [in English].

17. Aulin V., Lysenko S., Hrynkiv A., Chernai A., Zhylova I., Lukashuk A. (2019). Wear resistance increase of samples tribomating "Steel 45-cast iron SCH20" with geo modifier KGMF-1. Problemy trybolohii. Khmelnytskyi. KhNU, №2 S.55-60 [in English].

18. Aulin V., Hrynkiv A., Lysenko S., Lyashuk O., Zamota T., Holub D. (2019). Studying the tribological properties of mated materials C61900-A48-25BC1.25BNo.25 in composite oils containing geomodifiers. Eastern-European Journal of Enterprise Technologies. Vol. 5 (12-101). P. 38-47 [in English].

19. Aulin V., Lyashuk O., Hrynkiv A., Lysenko S. at all. (2019). Determination of the rational composition of the additive to oil with the use of the Katerynivka friction geo modifier. Tribology in Industry. Vol. 41. No. 4. P.548-562 [in English].

20. Aulin V., Hrynkiv A., Lysenko S., Zamota T., Pankov A., Tykhyi A. (2019). Determining the rational composition of tribologically active additive to oil to improve characteristics of tribosystems. Eastern-European Journal of Enterprise Technologies. Vol. 6 (12-102). P. 52-64 [in English]

21. Aulin V.V., Lysenko S.V., Hrynkiv A.V. (2019). Model nadiinosti detalei transportnykh mashyn za protsesamy realizatsii trybotekhnolohii yikh prypratsiuvannia i vidnovlennia [The model of reliability of details of transport cars on processes of realization of tribotechnologies of their running in and restoration]. Tsentralnoukrainskyi naukovyi visnyk. Tekhnichni nauky - Central Ukrainian Scientific Bulletin. Technical sciences, Vyp. 2(33). S.50-64 [in Ukrainian].

22. Aulin V.V., Hrynkiv A.V., Lysenko S.V., Chernai A.Ie., Lukashuk A.P. (2020) Protses zminy stanu olyvy pry prypratsiuvanni spriazhen detalei ta obkattsi dvyhuniv transportnykh mashyn [The process of changing the state of the oil during the running-in of the couplings of parts and running-in of engines of transport machines]. Increase of Machine and Equipment Reliability: materialy Mizhnarodnoi naukovo-praktychnoi konferentsii - materials of the International scientific-practical conference, $15-17$ kvitnia 2020 r., Kropyvnytskyi: TsNTU, S.162-165 [in Ukrainian].

23. Aulin V.V., Lysenko S.V., Hrynkiv A.V., Chernai A.Ie., Lukashuk A.P. (2020). Optymalne keruvannia rezhymamy funktsionuvannia trybospriazhenniamy detalei system i ahrehativ transportnykh mashyn [Optimal control of modes of operation of tribocouples of details of systems and units of transport cars]. Increase of Machine and Equipment Reliability: materialy Mizhnarodnoi naukovo-praktychnoi konferentsii - materials of 
the International scientific-practical conference, 15-17 kvitnia 2020 r., Kropyvnytskyi: TsNTU, S.178-179 [in Ukrainian].

24. Aulin V.V. (2015). Trybofizychni osnovy pidvyshchennia znosostiikosti detalei ta robochykh orhaniv silskohospodarskoi tekhniky [Tribophysical bases of increase of wear resistance of details and working bodies of agricultural machinery].- Doctor's thesis, Khmelnyts. nats. un-t. Khmelnytskyi, [in Ukrainian].

25. Pat. 81598 Ukraïna, MPK (2013) C10M 125/04. Prypratsiuvalna mastylna kompozytsiia [Running lubricating composition]. V.V. Aulin, V.V. Slon, S.V. Lysenko, D.V. Holub; zajavnik i vlasnik Kirovohradskyi nats. tekhn. universytet no. u201213907 ; zajavl. 06.12.2012; opubl. 10.07.13, Bjul. no. 13, [in Ukrainian].

26. Aulin V., Lysenko S., Hrynkiv A., Chernai A. at all. (2020). New approach to elucidating the physical nature of the processes that occur in the friction zone of mates of machine parts. Problems of tribology. Khmelnytskyi. KhNU, 25 (4/98). S.13-19 [in English]. 
Аулін В.В., Лисенко С.В., Гриньків А.В., Слонь В.В., Чернай А.Е. Створення теоретичних основ триботехнологій припрацювання і відновлення як засобу ефективного підвищення експлуатаційної зносостійкості автотранспортної та мобільної сільськогосподарської техніки

Визначено підстави для створення теоретичних основ триботехнологій припрацювання i відновлення спряжень деталей систем і агрегатів автотранспортної та мобільної сільськогосподарської техніки.

Розглянуто специфіку вибіркового переносу на поверхні контактуючих деталей машин та створення сервовитних плівок, формування покриттів при припрацюванні і відновленні 3 антифрикційних матеріалів, що входять до складу присадок в моторну та трансмісійну оливу.

3'ясовано ряд трибофізикохімічних процесів, які відбуваються в спряженнях матеріалів деталей, та як вони впливають на створення триботехнологій припрацювання та відновлення. Розглянуто створення триботехнологій при використанні геомодифікаторів. Запропоновано єдину теорію триботехнологій припрацювання і відновлення будувати на основі механізму утворення трибоплазми в спряженнях деталей систем і агрегатів машин. Також запропоновано до цього додати термофлуктуаційну теорію C.M. Журкова 3 урахуванням зміни дилатонних i компресонних зв'язків атомів матеріалів трибоспряжень деталей 3 створенням локальних областей деформацій стиску i розтягу та зон термопластичної деформації.

Ключові слова: триботехнології припрацювання і відновлення, спряження деталей, трибоплазма, олива, присадка, автотранспортна техніка, мобільна сільськогосподарська техніка. 